\title{
ТИПОЛОГІЧНЕ РІЗНОМАНІТТЯ ЛІСІВ НА ВОДОЗБОРАХ РІЧОК ЛІВОБЕРЕЖНОГО ЛІСОСТЕПУ УКРАЇНИ
}

\author{
Бондар О. Б., Ткач Л. I.
}

\section{ВСТУП}

Прагнення науковців класифікувати конкретні ділянки лісу виникли 3 практичної необхідності продуманої організації та ведення лісового господарства. Перші схеми класифікації лісів були запропоновані Г.Ф. Морозовою, А.А. Крюденером, Є.В. Алексєєвою та іншими вченими, вони заклали основу для майбутніх класифікацій лісових насаджень ${ }^{1}$.

Найбільш розроблену та досконалу класифікацію насаджень на базі попередніх лісотипологічних робіт розробив П.С. Погребняк. Основою його класифікації є едафічна сітка, побудована на координатах багатства та вологості грунту ${ }^{2}$. Значний внесок у розвиток лісової типології зробив Д.В. Воробйов, який розробив таксономічні лісотипологічні одиниці: тип лісової ділянки, тип лісу та тип деревостану ${ }^{3}$.

Опубліковано цикл робіт ${ }^{4,5,6}$, які розкривають методичні положення української лісотипологічної школи й узагальнюють отримані результати. Наступні наукові роботи завершилися створенням кадастру - повного опису всіх поширених типів лісу рівнинної території України. Для зони широколистяних лісів було виділено й описано 55 типів лісу. Майже однакова кількість типів лісу в кожній лісорослинній зоні: у Поліссі - 51, Лісостепу - 47, та Степу -51 .

${ }^{1}$ Остапенко Б.Ф., Ткач В.П. Лісова типологія : навчальний посібник. Харків : 2002. 204 c.

${ }^{2}$ Погребняк П.С. Основы лесной типологии ; изд. 2-е. Киев : АН УССР, 1955. $456 \mathrm{c}$.

${ }^{3}$ Воробьев Д.В. Методика лесотипологических исследований. Киев : Урожай, 1967. $330 \mathrm{c}$.

4 Остапенко Б.Ф. Типологічна різноманітність лісів України: Лісостеп. Харків : XHAУ, 1997. $128 \mathrm{c}$.

5 Остапенко Б.Ф., Улановский М.С. Типологическое разнообразие лесов Украины. Степь. Харьков : Харьковский государственный аграрный университет, 1999. $157 \mathrm{c}$.

${ }^{6}$ Остапенко Б.Ф., Федець І.П., Пастернак В.П. Типологічна різноманітність лісів України. Зона широколистяних лісів. Харків : ХДАУ ім. В.В. Докучаєва. 1997. 127 с. 
Поширення типів лісу на водозборах річок досліджували: В.П. Ткач - для заплавних лісів ${ }^{7}$, В.В. Горошко - річки Сіверський Донець та іï притоків ${ }^{8}$, Л.І. Ткач і О.Б. Бондар - річки Сула, Псел, Ворскли, Сіверський Донець та їхні притоки, вони дослідили типологічну структуру лісів яку в подальшому необхідно врахувати під час планування, організації та проведення лісогосподарських заходів на водозборах річок ${ }^{9,10,11,12,13}$.

Усього в Україні науковцями детально описано 257 типів лісу і ще близько 20-30 типів лісу додатково виділено без детального опису ${ }^{14}$. Тому $є$ необхідність уточнити перелік типів лісу та виділити таку їх кількість, яка існує на водозборах річок.

Переведення господарювання на водозбірно-ландшафтний рівень слід здійснювати в декілька етапів. На першому етапі визначають нормативи, що дають можливість установити мінімальну площу водозбору залежно від географічної зони, рельєфу, геоморфологічних особливостей території тощо, а також просторової організації та структури водозбору. На другому етапі визначають стратегію оптимізації структури водозбору, у тому числі лісистості, розробляють план трансформації угідь 3 урахуванням перспектив розвитку господарств та необхідності поступового досягнення екологічної збалансованості водозбору. На третьому етапі впроваджують системи

${ }^{7}$ Ткач В.П. Заплавні ліси України. Харків : Право, 1999. 368 с.

${ }^{8}$ Горошко В.В. Лісистість водозборів річок середньої течії Сіверський Донець та особливості формування лісів на них : автореф. дис. ... канд. с.-г. наук : спец. 06.03.03. Харків. 2012. 21 с.

${ }^{9}$ Tkach V., Bondar O., Rumiantsev M., Pedunculate oak stands in the catchments of the river Vorskla's tributaries. Folia Oecologica. 2020. № 47(1). P. 64-74. DOI: https://doi.org/10.2478/foecol-2020-0009.

${ }^{10}$ Prevailing forest types in the river catchments within the Left-Bank Forest-Steppe zone, Ukraine / O. Bondar et al. Folia Forestalia Polonica, Series A - Forestry. 2020. Vol. 62(2). P. 100-113. DOI: https://doi.org/10.2478/ffp-2020-0011.

${ }^{11}$ Сучасний стан дубових насаджень на притоках Ворскли у межах Сумської області та особливості їх природного відновлення / О.Б. Бондар та ін. Науковий вісник НЛТУ України. 2020. № 30(4). С. 19-24. URL: https://doi.org/10.36930/40300403.

12 Бондар О.Б., Румянцев М.Г. Корінні й похідні типи деревостанів у найбільш поширених типах лісу на водозборах річок Лівобережного Лісостепу. Вісник Уманського національного університету садівництва. 2019. № 2019. С. 76-81. DOI: https://doi.org/10.31395/2310-0478-2019-1-76-81 .

13 Бондар О.Б. Лісистість і лісівничо-таксаційні особливості насаджень водозборів річок Лівобережного Лісостепу. Лісівництво і агролісомеліорація. 2018. Вип. 132. С. 13-24. DOI: https://doi.org/10.33220/1026-3365.132.2018.13.

14 Ткач В.П. Сучасні проблеми лісівничо-екологічного напряму в лісовій типології. Науковий вісник НУБіПУ. Серія «Лісівнищтво та декоративне садівниитво». 2012. Вип. 171. Ч. 3. С. 230-238. 
господарювання, що враховують специфічні особливості конкретного водозбору. Реалізація такої організації і ведення господарства $\epsilon$ важливим завданням, що потребує вирішення.

Для виділення меж водозборів річок Сула, Псел, Ворскла, Сіверський Донець використовували програму MapInfo Professional 12.5 і векторну карту України.

Межі водозбірної площі визначали за вододільними лініями, які проходять через точки, від яких лінії схилу розходяться у різні боки. Розміщуються такі точки у місцях найбільшого вигину горизонталей. Вододіли проходять за лініями хребтів через вершини та сідловини.

Для аналізу поширення типів лісу в межах лісового фонду лісогосподарських підприємств на водозборах річок Сула, Псел, Ворскла й Сіверський Донець використали електронну базу даних ВО «Укрдержліспроєкт», яку конвертували з формату .vff у формат .mdb програмного продукту MS Access за допомогою програм NewUnPackOHOTA, розроблених у лабораторії нових інформаційних технологій УкрНДІЛГА. Вибірки даних, необхідних для подальших обчислень, експортували у формат .xls програми Microsoft Excel ${ }^{15}$.

Під час типологічного аналізу лісів використано методичні положення української лісотипологічної школи ${ }^{16,17}$. Аналіз дослідних даних проведено з використанням прикладних комп'ютерних програм, а також геоінформаційних технологій.

\section{1. Характеристика регіону досліджень}

Лівобережний Лісостеп охоплює територію Придніпровської низовини та південно-західних схилів Середньоруської височини. Клімат континентальний. Річна амплітуда температури повітря становить $27,4^{\circ} \mathrm{C}$, сума середньомісячних плюсових температур $98,3^{\circ} \mathrm{C}$. На рік випадає від 457 до 614 мм опадів. За лісотипологічним районуванням територія Лівобережного Лісостепу належить до області свіжого помірно теплого клімату (свіжого груду 2d), зокрема двох лісотипологічних районів - Слобожанського ясенево-липових дібров i

${ }^{15}$ Ведмідь М.М., Мєшкова В.Л., Жежкун А.М. Алгоритм для виявлення земель малоцінних молодняків у дібровах за матеріалами лісовпорядкування. Лісівництво $i$ агролісомеліорація. 2006. Вип. 110. С. 54-59.

${ }^{16}$ Остапенко Б.Ф., Ткач В.П. Лісова типологія : навчальний посібник. Харків, 2002. 204 c.

17 Погребняк П.С. Основы лесной типологии ; изд. 2-е. Киев : АН УССР, 1955. $456 \mathrm{c}$. 
Дніпровського свіжих грабових дібров і трьох секторів:Лівобережного, Ворскло-Псельського та Придонецького ${ }^{18}$.

Регіон дослідження охоплює територію двох водних басейнів (рис. 1): Дніпровського (водозбори Сули, Псла й Ворскли) та Донського (водозбір Сіверського Дінця).

У межах Лівобережного Лісостепу водозбір Сули розташований на території Сумської, Полтавської, Чернігівської, Черкаської й Київської областей. Водозбір Псла і Ворскли розташований лише на території Сумської та Полтавської областей, а водозбір Сіверського Дінця - лише на території Харківської області.

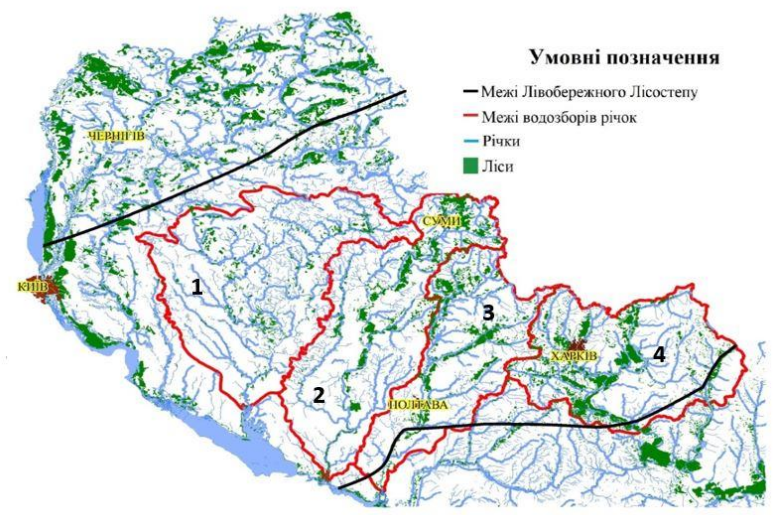

Рис. 1. Схема-карта водозборів Сули (1), Псла (2), Ворскли (3) та Сіверського Дінця (4)

Площа водозборів річок, визначена нами за допомогою програми Mapinfo Professional 12.5 (trial) i векторних карт на території Лівобережного Лісостепу, $\epsilon$ найбільшою на водозборах Сули $\left(18,6\right.$ тис км $\left.{ }^{2}\right)$ та Псла $(16,3$ тис км²), а найменшою - на водозборах Сіверського Дінця $(14,1$ тис км²) та Ворскли $(11,9$ тис км²).

За даними ВО «Укрдержліспроєкт» (станом на 01.01.2011), найбільшою $\epsilon$ площа лісів на водозборі Сіверського Дінця (176,9 тис га), Псла (137,8 тис га) та Ворскли (119,2 тис га), а найменшою - на водозборі Сули (68,1 тис га).

На водозборах Псла і Ворскли насадження поширені переважно в долинах верхньої та середньої течій річок. На водозборі Сули ліси

18 Остапенко Б.Ф., Ткач В.П. Лісова типологія : навчальний посібник. Харків, 2002. 204 c. 
поширені найбільше на правому березі та переважно зосередженні в середній течії, а на водозборі Сіверського Дінця - у долинах і ярах на верхній, середній і нижній течіях річки.

Усі водозбори розглянутих річок мають витоки із Середньоруської височини. Водозбори Сули, Псла та Ворскли нижче перетинають Придніпровську низовину, а водозбір Сіверського Дінця перетинає Донецький кряж ${ }^{19,20,21,22,23}$.

Похил річки $є$ найбільшим на водозборах Ворскли (0,30 м/км), на водозборах Псла й Сули становить 0,23 та 0,2 м/км відповідно, а найменшим $\epsilon$ на водозборах Сіверського Дінця $(0,18$ м/км), що відбивається на особливостях поширення типів лісу.

Характер формування та поширення лісів на водозборах річок залежить від геоморфологічної будови, грунтових умов, рельєфу місцевості та кліматичних особливостей, що необхідно брати до уваги під час планування, організації та ведення лісового господарства

Живлення водозборів Сули, Псла, Ворскли й Сіверського Дінця $\epsilon$ мішаним. Основні притоки Сули, Псла, Ворскли та Сіверського Дінця наведено в табл. 1.

Таблиця 1

Основні притоки Сули, Псла, Ворскли та Сіверського Дінця

\begin{tabular}{|c|c|c|c|c|}
\hline \multirow{2}{*}{$\begin{array}{r}\text { Основні } \\
\text { притоки }\end{array}$} & \multicolumn{4}{|c|}{ Водозбір річки } \\
\hline & Сула & Псел & Ворскла & Сів. Донець \\
\hline Ліві & $\begin{array}{l}\text { Вільшанка, } \\
\text { Артополот }\end{array}$ & $\begin{array}{c}\text { Грунь, } \\
\text { Хорол, } \\
\text { Сироватка }\end{array}$ & $\begin{array}{c}\text { Мерла, } \\
\text { Свинківка, } \\
\text { Тагамлик }\end{array}$ & $\begin{array}{l}\text { Вовча, Хотімля, } \\
\text { Гнилиця, Середня } \\
\text { Балаклійка, Оскіл }\end{array}$ \\
\hline Праві & $\begin{array}{c}\text { Терн, } \\
\text { Хмелівка, } \\
\text { Ромен, } \\
\text { Лохвиця, } \\
\text { Сулиця, } \\
\text { Сліпорід, } \\
\text { Удай, } \\
\text { Оржиця }\end{array}$ & $\begin{array}{c}\text { Грунь- } \\
\text { Ташань, } \\
\text { Говтва }\end{array}$ & $\begin{array}{c}\text { Ворсклиця, } \\
\text { Боромля }\end{array}$ & Бабка, Уда, Мож \\
\hline
\end{tabular}

${ }^{19}$ Географічна енциклопедія України : у 3-х т. / редкол.: О.М. Маринич (відп. ред.) та ін. Київ : Українська енциклопедія, 1989, Т. 1: А-Ж ; 1990. Т. 2: 3-О. 479 с. ; 1993. Т. 3: П-Я. 479 с.

${ }^{20}$ Гідрохімія річок Лівобережного Лісостепу України : навчальний посібник / за ред. В.К. Хільчевського, В.А. Сташука. Київ : Ніка-Центр, 2014. 230 с.

${ }^{21}$ Національний атлас України. Київ : ДНВП «Картографія», 2007. 440 с.

${ }^{22}$ Справочник по водным ресурсам ССCP. T. VIII. Украинская ССР. Ч. 1 / под ред. М.С. Каганера. Киев : АН УССР, 1954. 618 с.

${ }^{23}$ Справочник по водным ресурсам CCCP. T.VIII. Украинская ССР. Ч.2 / под ред. М.С. Каганера. Киев : АН УССР, 1955. 657 с. 
Геоморфологічна структура водозборів Лівобережного Лісостепу є різноманітною і характеризується своєрідними особливостями (табл. 2).

Таблиця 2

Геоморфологічна структура водозборів річок

\begin{tabular}{|c|c|c|c|c|}
\hline \multirow{2}{*}{ Геоморфологічна структура } & \multicolumn{4}{|c|}{ Водозбір річки } \\
\cline { 2 - 5 } & Сула & Псел & Ворскла & Сів. Донець \\
\hline $\begin{array}{c}\text { Східчаста горбисто-увалиста } \\
\text { рівнина на крейдових } \\
\text { палеоген-неогенових } \\
\text { відкладах }\end{array}$ & - & + & + & + \\
\hline $\begin{array}{c}\text { Субгоризонтальна увалиста } \\
\text { та горбисто-увалиста рівнина } \\
\text { на крейдових, палеогенових } \\
\text { і неогенових відкладах }\end{array}$ & + & + & + & + \\
\hline $\begin{array}{c}\text { Перша та друга } \\
\text { надзаплавні тераси }\end{array}$ & + & + & + & + \\
\hline $\begin{array}{c}\text { Третя та четверта } \\
\text { надзаплавні тераси }\end{array}$ & - & + & + & + \\
\hline $\begin{array}{c}\text { Перша, друга, третя та } \\
\text { четверта надзаплавні тераси }\end{array}$ & - & + & - & + \\
\hline $\begin{array}{c}\text { Четверта та п'ята } \\
\text { надзаплавні тераси }\end{array}$ & + & + & - & + \\
\hline $\begin{array}{c}\text { П'ята, шоста та сьома } \\
\text { надзаплавні тераси }\end{array}$ & - & - & + & + \\
\hline
\end{tabular}

Примітка: + траплясться геоморфологічна структура, - не траплясться геоморфологічна структура

Субгоризонтальна увалиста та горбисто-увалиста рівнина на крейдових, палеогенових i неогенових відкладах та перша i друга надзаплавні тераси трапляються на всіх водозборах Сули, Псла, Ворскли й Сіверського Дінця.

Східчаста горбисто-увалиста рівнина на крейдових i палеогеннеогенових відкладах, третя та четверта надзаплавні тераси поширені на водозборах Псла, Ворскли та Сіверського Дінця і відсутні на водозборі Сули.

Четверта та п'ята надзаплавні тераси трапляються лише на водозборах Сули й Псла, а п'ята, шоста й сьома надзаплавні тераси - лише на водозборах Ворскли та Сіверського Дінця.

Перша, друга, третя та четверта надзаплавні тераси трапляються лише на водозборах Псла і Сіверського Дінця.

На водозборах Сули, Псла та Ворскли трапляються локальні (блокові та плікативні) структури, виражені у рельєфі за комплексом ознак. 
Суфозійні западини, соляні куполи, виражені у рельєфі, трапляються лише на водозборах Псла та Ворскли, долини та улоговини стоку талих льодовикових вод - на водозборах Сули, Псла та Ворскли.

Гравітаційні зсуви, екзараційно-ерозійні зниження у підльодовиковому рельєфі трапляються лише на водозборі Сули.

Грунти на водозборах річок Лівобережного Лісостепу характеризуються великим різноманіттям. Так, на водозборі р. Сула переважають чорноземи типові добрегумусоакумулятивні в комплексі 3 лучнотиповочорноземними та у комплексі з чорноземно-лучними і солонцями лучно-чорноземними легкосуглинковими; лучно-типовочорноземні та у комплексі 3 чорноземно-лучними $\mathrm{i}$ солонцями лучно-чорноземними середньосуглинковими.

На водозборі Псла домінують чорноземи типові добрегумусоакумулятивні середньосуглинкові; лучно-типовочорноземні та у комплексі 3 чорноземно-лучними $\mathrm{i}$ солонцями лучно-чорноземними середньосуглинковими.

На водозборі Ворскли переважають чорноземи типові добрегумусоакумулятивні середньосуглинкові, чорноземи опідзолені помірно слабогумусоакумулятивні середньо i важкосуглинкові; темно-сірі опідзолені слабогумусоакумулятивні в комплексі 3 чорноземами опідзоленими помірно слабогумусоакумулятивними важко суглинковими.

На водозборі Сіверського Дінця домінують чорноземи типові добрегумусоакумулятивні важкосуглинкові, темно-сірі опідзолені слабогумусоакумулятивні важкосуглинкові та чорноземи опідзолені помірно слабогумусоакумулятивні важкосуглинкові.

Особливості геоморфологічної структури та видів грунтів на водозборах Лівобережного Лісостепу впливають на формування типів лісорослинних умов, типів лісу, а також на динаміку лісівничо-таксаційних показників різних за складом насаджень. Це необхідно врахувати під час ведення лісового господарства на водозборах річок.

\section{2. Кадастр типів лісу водозборів річок Лівобережного Лісостепу}

Лісовий фонд водозборів річок Лівобережного Лісостепу України характеризується великою різноманітністю типів лісорослинних умов, що охоплюють майже всю едафічну сітку Є.В. Алексєєва П.С. Погребняка. У кожній групі типів лісорослинних умов лісовпорядниками виділено різну кількість типів лісу. Бори представлені чотирма, субори - вісьмома, сугруди - двадцять дев'ятьма та груди дванадцять одним типом лісу. Загалом виділено 62 типи лісу на площі близько 502,0 тис га (рис. 1). Розподіл кількості типів лісу на водозборах такий: Сули й Псла - по 49, Ворскли - 46 і Сіверського Дінця - 32. 
Найбільш поширеним типом лісу на території дослідного регіону є свіжа кленово-липова діброва $\left(\mathrm{D}_{2}\right.$-клД), частка якої коливається від 25,9\% (водозбір Сули) до 55,4\% (водозбір Сіверського Дінця).

На значних площах насадження ростуть в умовах свіжого дубовососнового субору $\left(\mathrm{B}_{2}\right.$-дС). Найбільша частка цього типу лісу - на водозборах Псла і Ворскли (по 19,5\%), дещо менша - на водозборах Сіверського Дінця та Сули - 16,1\% і 8,5\% відповідно (табл. 3).

Таблиця 3

Розподіл площ типів лісу на водозборах річок, га

\begin{tabular}{|c|c|c|c|c|}
\hline Тип лісу & Сула & Псел & Ворскла & Сів. Донець \\
\hline $\mathbf{1}$ & $\mathbf{2}$ & $\mathbf{3}$ & $\mathbf{4}$ & $\mathbf{5}$ \\
\hline Дуже сухий сосновий бір & - & 50,9 & 22,5 & 4,9 \\
\hline Сухий сосновий бір & 2,6 & 2996,9 & 1124,1 & 1574,0 \\
\hline Вологий сосновий бір & 36,4 & 6250,6 & 7286,2 & 6309,2 \\
\hline Сирий сосновий бір & - & 1,3 & 19,7 & - \\
\hline $\begin{array}{c}\text { Сухий дубово-сосновий } \\
\text { субір }\end{array}$ & 80,3 & 300,1 & 561,2 & 2658,9 \\
\hline $\begin{array}{c}\text { Сухий дубовий субір } \\
\text { еродований }\end{array}$ & - & - & 3,7 & - \\
\hline $\begin{array}{c}\text { Свіжий дубово-сосновий } \\
\text { субір }\end{array}$ & 5799,1 & 26808,9 & 23285,6 & 28559,6 \\
\hline $\begin{array}{c}\text { Вологий дубово-сосновий } \\
\text { субір }\end{array}$ & 188,3 & 731,4 & 682,3 & 351,6 \\
\hline $\begin{array}{c}\text { Вологий заплавний } \\
\text { тополевий субір }\end{array}$ & 1,0 & 2,3 & 79,1 & 90,5 \\
\hline $\begin{array}{c}\text { Сирий дубово-сосновий } \\
\text { субір }\end{array}$ & 39,5 & 12,4 & 62,0 & 46,5 \\
\hline $\begin{array}{c}\text { Сирий дубово-сосновий } \\
\text { субір осушений }\end{array}$ & - & 0,8 & - & - \\
\hline $\begin{array}{c}\text { Мокрий березово-сосновий } \\
\text { субір }\end{array}$ & 0,9 & 1,0 & 55,5 & 1,7 \\
\hline $\begin{array}{c}\text { Суха пакленова судіброва } \\
\text { еродована }\end{array}$ & & 76,1 & 176,1 & 1069,5 \\
\hline $\begin{array}{c}\text { Суха чорнокленова } \\
\text { судіброва еродова }\end{array}$ & 146,8 & 137,3 & 328,2 & - \\
\hline Свіжа грабова судіброва & 3439,7 & - & - & - \\
\hline $\begin{array}{c}\text { Свіжа грабово-дубово- } \\
\text { сосновий суг руд }\end{array}$ & 3789,1 & 80,3 & 111,0 & - \\
\hline $\begin{array}{c}\text { Свіжа грабово-соснова } \\
\text { судіброва }\end{array}$ & 166,2 & - & - & - \\
\hline Свіжа судіброва & 60,5 & 246,9 & 117,9 & 1087,4 \\
\hline Свіжа судіброва еродова & 2368,2 & 505,0 & 1484,9 & - \\
\hline $\begin{array}{c}\text { Свіжа липова судіброва } \\
\text { еродована }\end{array}$ & - & - & 81,2 & 730,7 \\
\hline
\end{tabular}


Продовження таблиці 3

\begin{tabular}{|c|c|c|c|c|}
\hline 1 & 2 & 3 & 4 & 5 \\
\hline Свіжа заплавна судіброва & 464,7 & 2176,9 & 1268,6 & 751,6 \\
\hline $\begin{array}{l}\text { Свіжа еродована пакленова } \\
\text { судіброва }\end{array}$ & 8,8 & 12,7 & - & - \\
\hline $\begin{array}{c}\text { Свіжа кленово-липова } \\
\text { судіброва }\end{array}$ & 436,6 & 2002,4 & 1013,5 & - \\
\hline $\begin{array}{c}\text { Свіжа пакленова судіброва } \\
\text { деградована }\end{array}$ & - & 0,7 & 1,6 & - \\
\hline $\begin{array}{c}\text { Свіжий липово-дубово- } \\
\text { сосновий сугруд }\end{array}$ & 1345,4 & 11555,7 & 10911,6 & 5557,6 \\
\hline $\begin{array}{c}\text { Свіжа заплавна берестова } \\
\text { судіброва, слабогалогений } \\
\text { варіант } \\
\end{array}$ & - & 0,7 & 10,8 & - \\
\hline $\begin{array}{l}\text { Свіжа заплавна судіброва, } \\
\text { среднегалогений варіант }\end{array}$ & - & - & 313,6 & - \\
\hline Волога грабова судіброва & 744,2 & - & - & - \\
\hline $\begin{array}{c}\text { Вологий грабово-дубово- } \\
\text { сосновий сугруд }\end{array}$ & 503,3 & 86,7 & 16,7 & - \\
\hline $\begin{array}{c}\text { Волога грабово-соснова } \\
\text { судіброва }\end{array}$ & 46,7 & & & \\
\hline $\begin{array}{c}\text { Вологий дубово-ялиново- } \\
\text { сосновий сугруд }\end{array}$ & 0,9 & 1,4 & & \\
\hline Волога заплавна судіброва & 321,1 & 1434,1 & 891,9 & 385,5 \\
\hline $\begin{array}{c}\text { Волога кленово-липова } \\
\text { судіброва }\end{array}$ & 1186,3 & 427,1 & 170,2 & 262,7 \\
\hline $\begin{array}{c}\text { Вологий дубово-ялиново- } \\
\text { сосновий сугруд }\end{array}$ & 0,9 & 1,4 & & \\
\hline Волога заплавна судіброва & 321,1 & 1434,1 & 891,9 & 385,5 \\
\hline $\begin{array}{c}\text { Волога кленово-липова } \\
\text { судіброва }\end{array}$ & 1186,3 & 427,1 & 170,2 & 262,7 \\
\hline $\begin{array}{c}\text { Вологий липово-дубово- } \\
\text { сосновий сугруд }\end{array}$ & 136,6 & 2567,9 & 1238,8 & 441,9 \\
\hline $\begin{array}{c}\text { Сирий чорновільховий } \\
\text { сугруд }\end{array}$ & - & 2,5 & - & - \\
\hline $\begin{array}{c}\text { Сирий чорновільховий } \\
\text { сугруд осушений }\end{array}$ & 3832,4 & 2184,1 & 1761,7 & 710,8 \\
\hline $\begin{array}{c}\text { Сирий дубово-сосновий } \\
\text { сугрудок } \\
\end{array}$ & - & 2,7 & 2,8 & - \\
\hline $\begin{array}{c}\text { Сирий заплавний вербово- } \\
\text { тополевий сугруд } \\
\end{array}$ & 18,9 & 19,9 & 1,0 & - \\
\hline $\begin{array}{c}\text { Сирий тополево-вербовий } \\
\text { сугруд }\end{array}$ & 312,6 & 236,8 & 242,3 & 47,0 \\
\hline $\begin{array}{c}\text { Сирий грабово-дубово- } \\
\text { сосновий сугруд }\end{array}$ & 19,4 & - & - & - \\
\hline $\begin{array}{l}\text { Мокрий чорновільховий } \\
\text { сугруд }\end{array}$ & 1024,1 & 532,2 & 574,2 & 101,1 \\
\hline
\end{tabular}


Закінчення таблиці 3

\begin{tabular}{|c|c|c|c|c|}
\hline 1 & 2 & 3 & 4 & 5 \\
\hline $\begin{array}{c}\text { Суха бересто-пакленова } \\
\text { діброва } \\
\end{array}$ & - & - & - & 117,3 \\
\hline Суха грабова діброва & 2,0 & - & - & - \\
\hline $\begin{array}{c}\text { Суха кленово-липова } \\
\text { діброва }\end{array}$ & 199,3 & 1677,5 & 3325,4 & 24515,7 \\
\hline Свіжа грабова діброва & 13348,5 & 1004,3 & 501,0 & - \\
\hline $\begin{array}{c}\text { Свіжа заплавна } \\
\text { берестово-пакленова } \\
\text { діброва }\end{array}$ & 362,7 & 423,0 & 1038,2 & 229,7 \\
\hline $\begin{array}{c}\text { Свіжа кленово-липова } \\
\text { діброва }\end{array}$ & 17620,0 & 61673,3 & 55787,0 & 96188,9 \\
\hline $\begin{array}{c}\text { Свіжа липово-ясенова } \\
\text { діброва }\end{array}$ & 2317,0 & 2722,6 & 487,2 & 0,6 \\
\hline Волога грабова діброва & 913,7 & 205,1 & 316,3 & - \\
\hline $\begin{array}{c}\text { Волога берестово- } \\
\text { пакленова діброва } \\
\text { заплавна }\end{array}$ & 959,0 & 1183,0 & 1045,3 & 3028,9 \\
\hline $\begin{array}{c}\text { Волога кленово-липова } \\
\text { діброва }\end{array}$ & 1004,9 & 1964,9 & 589,8 & 439,9 \\
\hline $\begin{array}{c}\text { Волога липово-ясенова } \\
\text { діброва }\end{array}$ & 421,8 & 870,1 & 189,7 & 978,9 \\
\hline $\begin{array}{c}\text { Вологий заплавний } \\
\text { тополевий груд }\end{array}$ & 2,6 & - & - & - \\
\hline Волога ясенева діброва & 117,2 & - & - & - \\
\hline $\begin{array}{c}\text { Сирий чорновільховий } \\
\text { груд осушений }\end{array}$ & - & 13,8 & - & - \\
\hline $\begin{array}{l}\text { Сирий чорновільховий } \\
\text { груд }\end{array}$ & 2576,9 & 3176,6 & 979,3 & 490,6 \\
\hline Сира грабова діброва & 3,9 & - & - & - \\
\hline $\begin{array}{c}\text { Сирий заплавний } \\
\text { вербовий груд }\end{array}$ & 0,4 & 1,5 & 2,4 & - \\
\hline $\begin{array}{c}\text { Сира кленово-липова- } \\
\text { діброва }\end{array}$ & 1,8 & 6,6 & & - \\
\hline $\begin{array}{c}\text { Сирий заплавний } \\
\text { тополево-вербовий груд }\end{array}$ & 641,0 & 165,0 & 76,3 & 111,9 \\
\hline $\begin{array}{l}\text { Мокрий чорновільховий } \\
\text { груд }\end{array}$ & 1038,4 & 1271,0 & 975,1 & 50,7 \\
\hline $\begin{array}{c}\text { Мокрий заплавний } \\
\text { вербовий груд }\end{array}$ & 25,0 & 29,1 & 8,4 & 11,3 \\
\hline Усього & 68076,7 & $\mathbf{1 3 7 8 3 4 , 1}$ & 119221,9 & $\mathbf{1 7 6 9 0 7 , 1}$ \\
\hline
\end{tabular}

На водозборі Сули майже третину площі лісів займає грабовий комплекс типів лісу $\left(\mathrm{D}_{2}\right.$-гД, $\mathrm{C}_{2}$-гД, $\mathrm{C}_{2}$-гдС та ін.), що відрізняє його від водозборів Ворскли, Псла й Сіверського Дінця за типологічним i 
видовим різноманіттям лісів, що необхідно врахувати під час ведення лісового господарства в регіоні дослідження.

\section{3. Кількість типів лісу на водозборах річок}

Типи лісу виступають географічними формами типу лісової ділянки, у межах якої вони розрізняються за складом лісоутворюючих порід. Утворення типу лісу пов'язане 3 кліматом та історією формування сучасної флори. Якщо для деревної природної рослинності умови несприятливі, типи лісу заміщаються типами степів, лук ${ }^{24,25}$.

На водозборах Сули, Псла, Ворскли та Сіверського Дінця відрізняються представництвом типів лісу. Це обов'язково необхідно врахувати під час планування, організації та ведення лісового господарства. Усього на території дослідного об'єкта виділено 109 водозборів річок, на 35 водозборах річок виділено до 10 типів лісу, на 46 водозборах - 11-20 типів лісу, на 22 водозборах річок - 21-30 типів лісу, а на 6 водозборах річок - 31-40 типів лісу.

Так, на водозборах річок (притоки річок меншого порядку, або 3-го порядку) Вільшанка, Бобрик, Артополот, Крем'яна, Тагамлик, Рудка, Боромка, Булатець, Олава, Хмилівка, Хусь, Удава, Грязний, Вовнянка, Сумка, Гайворонка, Івани, Рябина, Охтирка, Тетліга, Бишків, Мілова, Гнилиця, Сухий Бурлук та ін. загальна кількість типів лісу не перевищує 10.

Від 11 до 20 типів лісу виявлено на водозборах річок Будаква, Оржиця, Сліпорід, Сулиця, Суха Лохвиця, Локня, Ромен, Хусть, Терн, Рибиця, Сироватка, Будилка, Веприк, Лютенька, Гнилиця, Говтва, Рудька, Омельник, Манжалея, Олешня, Братениця, Гусинка, Криничка, Хухра, Кустолова, Кобилячка, Полузір'я, Олешня, Бабка, Гомільша, Щербинка, Вовча, Повна, Хотімля, Великий Бурлук та ін.

На водозборах річок Вільшанка, Лигань, Вільшанка, Бобрик, Мужева, Грунь, Орешня, Тагамлик, Боромля, Ворсклиця, Уда, Мож, Гнилиця 1, Волоська Балаклійка, Оскіл та ін. лісовпорядкуванням виділено від 21 до 30 типів лісу. На водозборах річок Удай, ГруньТашань, Хорол, Мерла, Свинківка визначено 31-40 типів лісу.

${ }^{24}$ Остапенко Б.Ф. Типи лісу рівнинної території України. Вісник НЛТУ. 2003. Вип. 13.3. С. 27-42.

${ }^{25}$ Main problems in natural seed regeneration of pedunculate oak (Quercus robur L.) stands in Ukraine / M. Rumiantsev et al. Forestry Studies. 2018. № 69. P. 7-23. DOI: 10.2478/fsmu-2018-0008. 


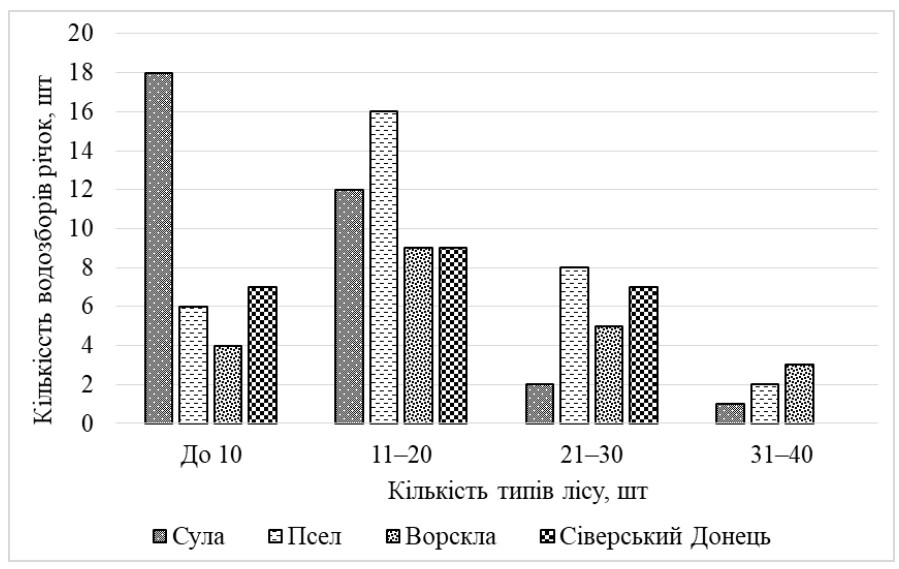

Рис. 2. Розподіл кількості типів лісу на водозборах річок, шт.

На водозборах менших річок (3-го порядку), що є притоками Сули, Псла, Ворскли та Сіверського Дінця, типологічне різноманіття лісів $€$ значно меншим, але також характеризується певними особливостями. Так, зі 109 досліджуваних водозборів лише на водозборах шести річок (Удай, Грунь-Ташань, Хорол, Мерла, Свинківка, без назви) виявлено понад 30 типів лісу, а на решті 103 водозборах кількість типів лісу не перевищувала 20 (табл. 2).

Водозбори річок 3-го порядку (притоки), що розміщені в північній частині Лівобережного Лісостепу, характеризувалися більшою кількістю типів лісу порівняно з водозборами південної частини.

Кількість типів лісу на водозборах Сули, Псла, Ворскли й Сіверського Дінця залежить від рельєфу та грунтово-кліматичних умов. Так, за умовно однорідних природних умов формується незначна кількість типів лісу (до 5 шт.), а за значної різноманітності природних умов кількість типів лісу зростає. Це необхідно врахувати під час ведення лісового господарства на водозборах річок.

Результати аналізу розподілу кількості типів лісу на водозборах Сули, Псла, Ворскли та Сіверського Дінця (рис. 3) свідчать, що на правому березі річок кількість типів лісу поступово зменшується від 45 (водозбір Сули) до 31 (водозбір Сіверського Дінця).

На лівому березі річок найбільша кількість типів лісу зосереджена на водозборах Псла (49 шт.) і Ворскли (42 шт.), а найменша - на водозборі Сіверського Дінця (26 шт.). 


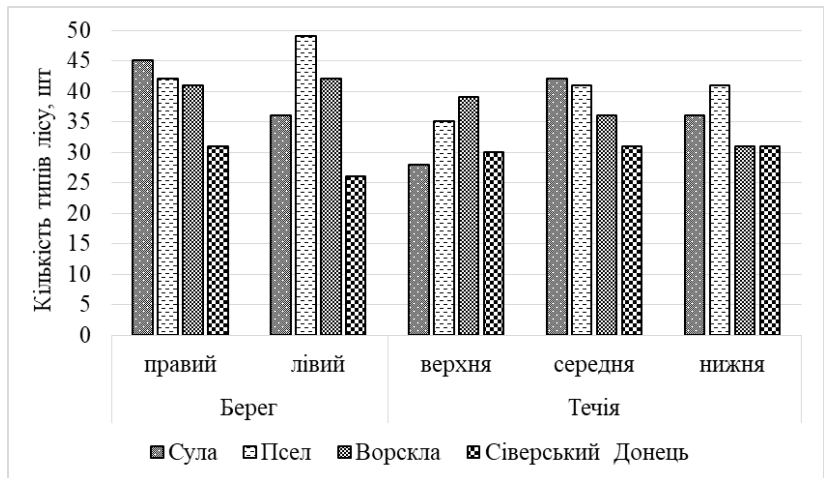

Рис. 3. Розподіл кількості типів лісу на водозборах річок за берегами та течіями, шт.

Виявилося також, що більшість типів лісу формується у верхній течії на водозборах Ворскли і Псла - 42 і 49 шт., а найменша - на водозборі Сіверського Дінця - 26 шт. У середній та нижній течіях річок найбільша кількість типів лісу зосереджена на водозборах Сули (42 і 36 шт. відповідно) та Псла (по 41 шт.), а найменша - на водозборах Ворскли (36 і 31 шт. відповідно) та Сіверського Дінця (по 31 шт.).

Розподіл типів лісу за трофотопами (табл. 3) свідчить, що найбільшу кількість типів лісу виявлено у сугрудах (29 шт.) і грудах (21 шт.), значно менше у суборах (8 шт.), а бори представлені лише чотирма типами лісу.

Таблиця 3

Розподіл кількості типів лісу на водозборах річок за трофотопами, шт.

\begin{tabular}{|c|c|c|c|c|c|}
\hline \multirow{2}{*}{$\begin{array}{c}\text { Водозбір } \\
\text { річки }\end{array}$} & \multicolumn{4}{|c|}{ Трофотоп } & \multirow{2}{*}{ Усього } \\
\cline { 2 - 5 } & А- бір & В - субір & С - сугруд & D - груд & \\
\hline Сула & $2 / 2^{*}$ & $6 / 6^{*}$ & $22 / 10^{*}$ & $19 / 11^{*}$ & $49 / 29^{*}$ \\
\hline Псел & $4 / 4^{*}$ & $7 / 6^{*}$ & $22 / 9^{*}$ & $16 / 11^{*}$ & $49 / 30^{*}$ \\
\hline Ворскла & $4 / 4^{*}$ & $7 / 5^{*}$ & $21 / 8^{*}$ & $14 / 10^{*}$ & $46 / 27^{*}$ \\
\hline Сів. Донець & $3 / 3^{*}$ & $6 / 5^{*}$ & $11 / 5^{*}$ & $12 / 9^{*}$ & $32 / 22^{*}$ \\
\hline Разом & $4 / 4^{*}$ & $8 / 6^{*}$ & $29 / 11^{*}$ & $21 / 13^{*}$ & $62 / 34^{*}$ \\
\hline
\end{tabular}

*Кількість типів лісу, які були описані науковцями

Типологічний аналіз наявних матеріалів та літературних даних засвідчує, що на водозборах Сули, Псла, Ворскли й Сіверського Дінця та їхніх приток у межах Лівобережного Лісостепу лісовпорядкуванням 
виділено 28 типів лісу, які не були виділені та описані в науковій літературі ${ }^{26,27}$.

Найбільшу кількість таких типів лісу виділено в сухих, свіжих і сирих сугрудах (18 типів лісу). Понад удвічі менше типів лісу (8 типів лісу) виділено в сухих, сирих і мокрих грудах, а найменше (лише 2 типи лісу) - у сухих і мокрих суборах (табл. 4). Це свідчить про необхідність уточнення списків типів лісу та їхніх діагностичних ознак як загалом для умов Лівобережного Лісостепу, так i в розрізі водозборів річок регіону.

Таблиця 4

\section{Типи лісу, які виділено лісовпорядкуванням} та не описано в науковій літературі ${ }^{28,29}$

\begin{tabular}{|c|c|c|c|}
\hline \multirow{2}{*}{ Гігротоп } & \multicolumn{3}{|c|}{ Трофотоп } \\
\hline & В - субір & С - сугруд & D - груд \\
\hline $1-$ сухий & $\mathrm{B}_{1}-Д^{\mathrm{e}}$ & $\mathrm{C}_{1}-$-Кп $Д^{\mathrm{e}}$ & $\mathrm{D}_{1}$-гД, $\mathrm{D}_{1}$-клД \\
\hline 2 - свіжий & - & 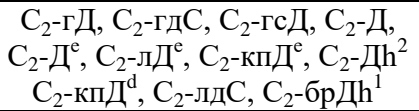 & - \\
\hline 3 - вологий & - & $\mathrm{C}_{3}$-гдС, $\mathrm{C}_{3}$-лдС & $\mathrm{D}_{3}-\mathrm{T}^{3}, \mathrm{D}_{3}$-ясД \\
\hline 4 - сирий & - & $\mathrm{C}_{4}$-дC, $\mathrm{C}_{4}$-тВp, $\mathrm{C}_{4}$-гд & $\begin{array}{c}\mathrm{D}_{4}-\mathrm{Bp}^{3}, \mathrm{D}_{4} \text {-клД, } \\
\mathrm{D}_{4}-\mathrm{TBp}^{3}\end{array}$ \\
\hline 5 - мокрий & $\mathrm{B}_{5}-$-бC & - & $\mathrm{D}_{5}-\mathrm{Bp}^{3}$ \\
\hline
\end{tabular}

Відмінності типологічного різноманіття лісів навіть у межах однієї природної зони, які зумовлені природними особливостями водозборів річок Сула, Псел, Ворскла та Сіверський Донець, необхідно враховувати під час уточнення лісотипологічного районування України. Відповідні таксони цього районування (сектори, райони, області) доцільно виділяти 3 урахуванням меж водозборів річок відповідного порядку.

\section{ВИСНОВКИ}

Типологічна структура лісів водозборів річок Лівобережного Лісостепу $є$ різноманітною. Вона представлена 62 типами лісу: на

26 Остапенко Б.Ф., Ткач В.П. Лісова типологія : навчальний посібник. Харків,2002. 204 с.

27 Остапенко Б.Ф., Федець І.П., Пастернак В.П. Типологічна різноманітність лісів України. Зона широколистяних лісів. Харків : ХДАУ ім. В.В. Докучаєва, 1997. 127 с.

${ }^{28}$ Остапенко Б.Ф., Ткач В.П. Лісова типологія : навчальний посібник. Харків, 2002. 204 c.

${ }^{29}$ Остапенко Б.Ф., Федець І.П., Пастернак В.П. Типологічна різноманітність лісів України. Зона широколистяних лісів. Харків : ХДАУ ім. В.В. Докучаєва, 1997. 127 с. 
водозборах Сули та Псла виявлено 49 типів лісу, на водозборах Ворскли - 46, на водозборах Сіверського Дінця - 32.

Найбільш поширеними типами лісу є свіжа кленово-липова діброва та свіжий дубово-сосновий субір.

Усього на території дослідного об'єкта виділено 109 водозборів річок, на 35 водозборах річок виділено до 10 типів лісу, на 46 водозборах - 11-20 типів лісу, на 22 водозборах річок - 21-30 типів лісу, а на 6 водозборах річок - 31-40 типів лісу.

Деякі типи лісу (28 шт.), які виділили лісовпорядники, не узгоджуються 3 переліком типів лісу, які визначено та описано в науковій літературі (для умов Лівобережного Лісостепу). Із метою вдосконалення ведення лісового господарства на водозборах річок необхідно уточнити перелік типів лісу та їхні діагностичні ознаки, а також розробити нове лісотипологічне районування з урахуванням меж водозборів річок.

\section{АНОТАЦІЯ}

Проведено дослідження поширення типів лісу на водозборах річок у межах Лівобережного Лісостепу на основі аналізу повидільної бази даних ВО «Укрдержліспроєкт». Загалом виділено 62 типи лісу на площі близько 502,0 тис га. Розподіл кількості типів лісу на водозборах такий: Сули й Псла - по 49, Ворскли - 46 і Сіверського Дінця - 32. Найбільш поширеними типами лісу $є$ свіжа кленово-липова діброва та свіжий дубово-соснового субір.

Проаналізовано розподіл кількості типів лісу на водозборах річок на берегах (лівий, привий) та течіях (верхня, середня, нижня). Усього на території дослідного об'єкта виділено 109 водозборів річок, на 35 водозборах річок виділено до 10 типів лісу, на 46 водозборах 11-20 типів лісу, на 22 водозборах річок - 21-30 типів лісу, а на 6 водозборах річок - 31-40 типів лісу.

Аналіз наявних матеріалів лісовпорядкування та літературних даних засвідчує, що на водозборах Сули, Псла, Ворскли й Сіверського Дінця було виявлено 28 типів лісу, які не були виділені та описані в науковій літературі.

\section{ЛITЕРАТУРА}

1. Остапенко Б.Ф., Ткач В.П. Лісова типологія : навчальний посібник. Харків, 2002. 204 с.

2. Погребняк П.С. Основы лесной типологии ; изд. 2-е. Киев : АН УССР, 1955. $456 \mathrm{c}$.

3. Воробьев Д.В. Методика лесотипологических исследований. Киев : Урожай, 1967. 330 с.

4. Остапенко Б.Ф. Типологічна різноманітність лісів України: Лісостеп. Харків : ХНАУ, 1997. 128 с. 
5. Остапенко Б.Ф., Улановский М.С. Типологическое разнообразие лесов Украины. Степь. Харьков : Харьковский государственный аграрный университет, 1999. $157 \mathrm{c}$.

6. Остапенко Б.Ф., Федець І.П., Пастернак В.П. Типологічна різноманітність лісів України. Зона широколистяних лісів. Харків : ХДАУ ім. В.В. Докучаєва, 1997. 127 с.

7. Ткач В.П. Заплавні ліси України. Харків : Право, 1999. 368 с.

8. Горошко В.В. Лісистість водозборів річок середньої течії Сіверський Донець та особливості формування лісів на них : автореф. дис. ... канд. с.-г. наук : спец. 06.03.03. Харків, 2012. 21 с.

9. Tkach V., Bondar O., Rumiantsev M. Pedunculate oak stands in the catchments of the river Vorskla's tributaries. Folia Oecologica. 2020. № 47(1). P. 64-74. DOI: https://doi.org/10.2478/foecol-2020-0009.

10. Prevailing forest types in the river catchments within the Left-Bank Forest-Steppe zone, Ukraine / O. Bondar et al. Folia Forestalia Polonica, Series A - Forestry. 2020. Vol. 62(2). P. 100-113. DOI: https://doi.org/10.2478/ffp-2020-0011.

11. Сучасний стан дубових насаджень на притоках Ворскли у межах Сумської області та особливості їхнього природного відновлення / О.Б. Бондар та ін. Науковий вісник НЛТУ Украйни. 2020. № 30(4). C. 19-24. URL: https://doi.org/10.36930/40300403.

12. Бондар О.Б., Румянцев М.Г. Корінні й похідні типи деревостанів у найбільш поширених типах лісу на водозборах річок Лівобережного Лісостепу. Вісник Уманського національного університету садівниитва. 2019. № 2019.1. С. DOI: https://doi.org/10.31395/2310-0478-2019-1-76-81.

13. Бондар О.Б. Лісистість і лісівничо-таксаційні особливості насаджень водозборів річок Лівобережного Лісостепу. Лісівництво і агролісомеліоращія. 2018. Вип. 132. С. 13-24. DOI: https://doi.org/10.33220/1026-3365.132.2018.13.

14. Ткач В.П. Сучасні проблеми лісівничо-екологічного напряму в лісовій типології. Науковий вісник НУБіПУ. Серія «Лісівництво та декоративне садівництво». 2012. Вип. 171. Ч. 3. С. 230-238.

15. Ведмідь М.М., Мєшкова В.Л., Жежкун А.М. Алгоритм для виявлення земель малоцінних молодняків у дібровах за матеріалами лісовпорядкування. Лісівництво і агролісомеліорація. 2006. Вип. 110. C. 54-59.

16. Остапенко Б.Ф., Ткач В.П. Лісова типологія : навчальний посібник. Харків, 2002. 204 с.

17. Погребняк П.С. Основы лесной типологии ; изд. 2-е. Киев : АН УCCP, $1955.456 \mathrm{c}$.

18. Остапенко Б.Ф., Ткач В.П. Лісова типологія : навчальний посібник. Харків, 2002. 204 с. 
19. Географічна енциклопедія України : у 3-х т. / редкол.: О.М. Маринич (відп. ред.) та ін. Київ : Українська енциклопедія, 1989. Т. 1: А-Ж. 414 с. ; 1990. Т. 2: 3-О. 479 с. ; 1993. Т. 3: П-Я. 479 с.

20. Гідрохімія річок Лівобережного Лісостепу України : навчальний посібник / за ред. В.К. Хільчевського, В.А. Сташука. Київ : Ніка-Центр, 2014. $230 \mathrm{c}$.

21. Національний атлас України [Карти]. Київ : ДНВП «Картографія», 2007. 440 с.

22. Справочник по водным ресурсам ССCP. T. VIII. Украинская ССР. Ч. 1 / под ред. М.С. Каганера. Киев : АН УССР, 1954. 618 с.

23. Справочник по водным ресурсам CССР. T.VIII. Украинская ССР. Ч. 2 / под ред. М.С. Каганера. Киев : АН УССР, 1955. 657 с.

24. Остапенко Б.Ф. Типи лісу рівнинної території України. Вісник НЛТУ. 2003. Вип 13.3. С. 27-42.

25. Main problems in natural seed regeneration of pedunculate oak (Quercus robur L.) stands in Ukraine / M. Rumiantsev et al. Forestry Studies. 2018. 69. P. 7-23. DOI: https://doi.org/10. 2478/fsmu-2018-0008.

26. Остапенко Б.Ф., Ткач В.П. Лісова типологія : навчальний посібник. Харків, 2002. 204 с.

27. Остапенко Б.Ф., Федець І.П., Пастернак В.П. Типологічна різноманітність лісів України. Зона широколистяних лісів. Харків : ХДАУ ім. В.В. Докучаєва, 1997. 127 с.

28. Остапенко Б.Ф., Ткач В.П. Лісова типологія : навчальний посібник. Харків, 2002. 204 с.

29. Остапенко Б.Ф., Федець І.П., Пастернак В.П. Типологічна різноманітність лісів України. Зона широколистяних лісів. Харків : ХДАУ ім. В.В. Докучаєва, 1997. 127 с.

Information about the authors: Bondar O. B.,

Candidate of Agricultural Sciences (Ph. D.), Senior Lecturer at the Department of Biology, Ecology and Methods of Teaching Them Taras Shevchenko Regional Humanitarian-Pedagogical Academy of Kremenets 1, Litseina str., Kremenets, Ternopil region, 47003, Ukraine

Tkach L. I.,

Candidate of Agricultural Sciences (Ph. D.), Associate Professor, Associate Professor at the Department of Engineering Ecology of Cities

O. M. Beketov National University of Urban Economy in Kharkiv 17, Marshala Bazhanova str., Kharkiv, 61000, Ukraine 